\title{
PRELIMINARY ANALYSIS OF EARTHEN ARCHITECTURE RESPONSE TO FLOODS: THE CASE OF ALZIRA (SPAIN)
}

\author{
F. Trizio ${ }^{1,3, *}$, C. Mileto ${ }^{1,3}$, F.J. Torrijo Echarri ${ }^{2,3}$, M. Lidón de Miguel ${ }^{1,3}$ \\ ${ }^{1}$ Departamento de Composición Arquitectónica, Universitat Politècnica de València, Valencia, España - fratri@ upvnet.upv.es, \\ cami2@cpa.upv.es, malidde@upv.es \\ 2 Departamento de Ingeniería del Terreno, Universitat Politècnica de València, Valencia, España - fratorec@ttr.upv.es \\ ${ }^{3}$ Research Centre PEGASO, Universitat Politècnica de València, Valencia, Spain
}

Commission II - WG II/8

KEY WORDS: Earthen Architecture, Rammed Earth, Floods, Risk Assessment, Conservation, Architectural Heritage

\begin{abstract}
:
Alzira, the capital of the Ribera del Júcar, has historically played a prominent role within the Comunitat Valenciana. The first settlement of the city dates back to the Moorish domination, and after the Reconquista, together with Xativa, Alcoi and Elx, it became one of the main cities of the ancient Reino de Valencia. Its architectural heritage is a witness of this remarkable past, including the glorious example of the Moorish wall, built almost entirely using the technique of rammed earth. Throughout history, the Moorish wall and the entire architectural heritage of Alzira have suffered extensive damage due to multiple factors, including neglect, wars and numerous floods. Throughout history, floods have had a significant impact on the architectural and cultural heritage of the city, as chronicled at the time, given that until the 1960s, the historic centre was surrounded by the two branches of the river Júcar. This study aims to analyse the response of earthen architecture to flooding, assessing its resilience and vulnerability through the analysis of the case of the city of Alzira and, in particular, of its historic centre. The research will therefore investigate the adaptation of earthen architecture and traditional techniques to floods. The recognition of these good practices used in the past and the establishment of a level of risk will be crucial to developing measures for the prevention and mitigation of the effects of floods, such as structural reinforcements and protective devices.
\end{abstract}

\section{INTRODUCTION}

\subsection{Floods: a natural risk}

Flooding, as a natural risk, can be defined based on the triggering cause. Internationally, the European Flood Directive 25-2018 defines different types of flooding: river floods, tropical rains, flash floods and coastal floods. This distinction has enabled the development of multiple methodologies for risk assessment and management. In addition to the document "INFORM 2019 - Index for risk management", a major global reference on the issue of risk management, extensive documentation can be found among European directives and documents relating to natural hazards.

At national level, it is possible to refer to the risk maps drawn up by the National Geographic Institute (www.ign.es) and to the "Guía Metodológica para la elaboración de riesgos en España" edited by the Colegio de Geologos de España in 2008, containing a detailed risk classification, with particular reference to the urban and territorial scale. In addition, it is clear that in recent years the considerable increase in the number of floods due to climate change has brought about alternating violent rains and periods of total absence of rainfalls, and a noticeable increase in temperatures, which are all particularly dangerous for the Iberian Peninsula.

\subsection{The town of Alzira}

The town of Alzira is located in the basin of River Júcar, about $40 \mathrm{~km}$ south of Valencia, the capital of the Comunitat Valenciana. The name Alzira probably has Arab origins and is believed to be a derivation of Al-gazira and Algezira Xucar, which mean "the island" and "the island of the Júcar" respectively (Montagut, 1989). This strongly suggests that the city's name is a characterization, providing a clear description of the historic centre, which was surrounded by the two branches of the river until last century.

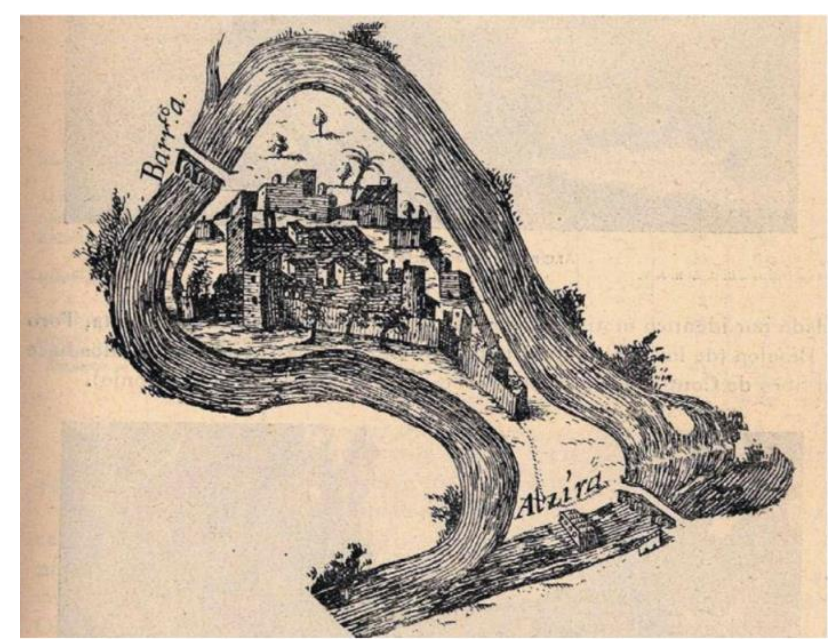

Figure 1. Historical representation of Alzira. (PEP - Alzira)

The border of the historic town or "Vila" of Alzira, marked by its Moorish wall, represents the outline of its primitive settlement, in a particularly unique site that has always prompted the interest of its visitors. The Vila was divided into two well-defined areas.

\footnotetext{
* Corresponding author
} 
The smaller area, located near the gate of Santa Maria (or of Valencia), included the medieval church of Santa Maria, now demolished; while the larger area was crossed by the Calle Mayor, which linked the two bridges of the city. The main and most representative buildings of the city, such as the Church of Santa Catalina and the Casa de la Vila, were located on this street (Lairón Pla, 2017).

The specific configuration of the Vila as a river island probably influenced the development and urban layout of the city, as well as its buildings. Although the river was a natural defence against external dangers, it has also always been a threat to the city, which has often been affected by the floods of the Júcar. In 1795, the botanist Cavanilles, describing the city of Alzira in his work "Observaciones sobre el Reyno de Valencia", emphasizes the particular configuration of the town embraced by its river and warns of the dangers of possible flooding (Tabernes et al., 2017). In fact, flooding can be identified as one of the main causes of deterioration - and often loss - of its architectural heritage. The constant threats posed by the river and the need for urban expansion necessitated the diversion of the smaller branch of the river, whose ancient riverbed was later reused for the construction of two large roads.

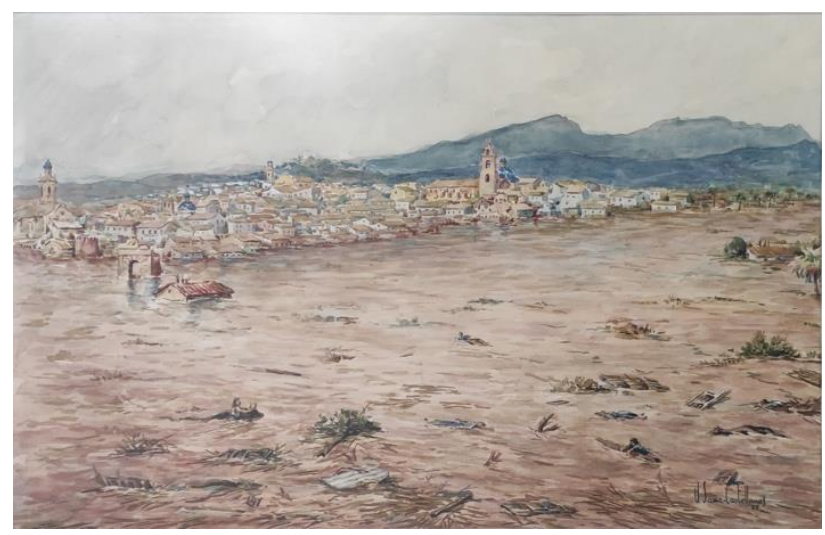

Figure 2. Alzira after the 1864 flood.

(Archivo Municipal de Alzira)

Nowadays, the old town has been largely modified by projects to widen the road sections, prompting the demolition of many buildings. Recently, in 2004, the Vila of Alzira received the highest protection from the Valencian Community (Declaration of Asset of Cultural Interest in the historic monument category. Decree 126/2004. DOGV no. 4811 of 03.08.2004), when it was declared cultural heritage. This declaration was followed by the Special Protection Plan of the Vila (PEP -Pla Especial De Protecció De La Vila D'Alzira, 2017), which aims to protect and preserve the historic centre.

\section{EARTHEN ARCHITECTURE AND FLOODING}

\subsection{The wall of Alzira}

In the historic centre of the Vila of Alzira, the role of the Moorish wall is of great historical and architectural interest. The wall is a defensive construction which, according to documents, dates back to the 13th century. It is built almost entirely of rammed earth, with merlons and semi-circular towers, and is an important example of monumental earthen architecture which has managed to survive the ravages of time, despite repeated exposure to floods and other causes of degradation.
The construction technique of compressed earth has very ancient origins, traceable to the technique of the opus formarium of the Phoenician era (Guillad, 2012).

Although individual cultures have developed their own unique technique of rammed earth, there are features which are common to any construction tradition (Guillad, 2012): the nature of the soil (sandy land, rich in gravel and poor in clay), the instruments (wooden formworks) and the construction process (to compact the earth with a ram). One of the weaknesses of earthen architecture is its sensitivity to water; this results in the formation of cracks in dry-wet cycles, decreasing the resistance of the structural system. Nevertheless, a major advantage for the conservation of the cultural heritage of earthen architectures is their reparability.

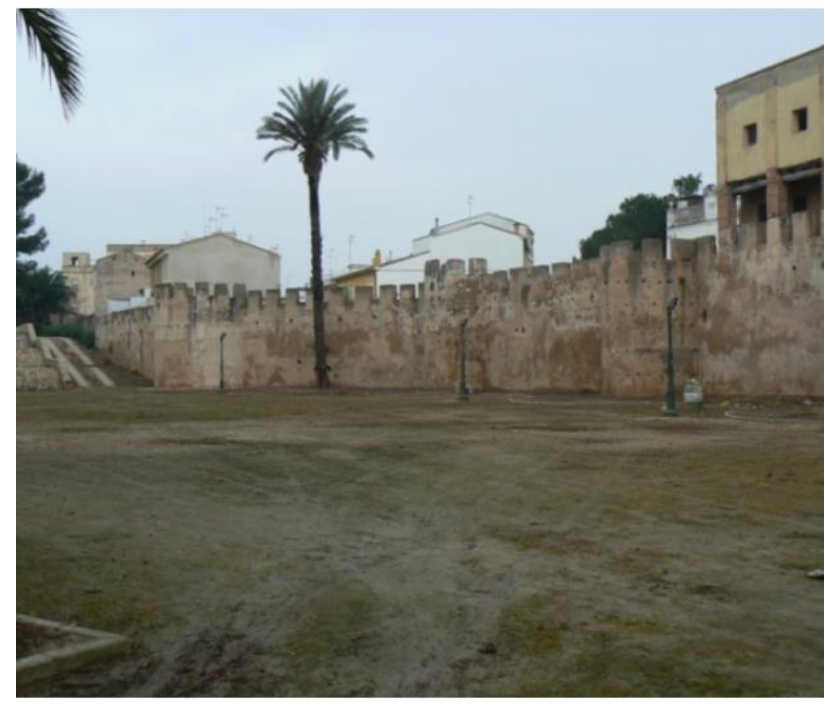

Figure 3. The Moorish wall (PEP - Alzira).

The Alzira Wall, built in Islamic times in the ancient territory of Sharq Al-Andalus, is the defensive construction that protected the urban citadel or al-qasaba (Hidalgo Mora, 2012).

The defensive function of the wall was two-fold, as it provided military defence from possible invasions while also acting as protection from the numerous floods of the river. This hypothesis is suggested by the semi-circular towers, since as opposed to square configurations, semi-circular shapes make it possible to avoid corners, which would suffer the greatest deterioration in case of flooding. One of the consequences of the frequent floods has been the gradual rise of the ground level; this has buried the lower section under deposits of detritus. Today the wall appears partially modified, as parts of it have been embedded between the adjacent buildings over the centuries, as can be seen in the towers and some areas of the wall. Between 1975 and 1982 the wall was restored creating a park with the wall (Parque de las Murallas), and in 1986, the new Parque de Arabia Saudi was opened to the public.

In 2019, the master's thesis in Architectural Heritage Conservation Las Murallas de Alzira by N. Mateo Mansanet (Master's in Architectural Heritage Conservation, Universitat Politècnica de València) analysed the state of conservation of the wall, which pinpointed rainfalls and capillarity from the ground as the main causes of its deterioration. 


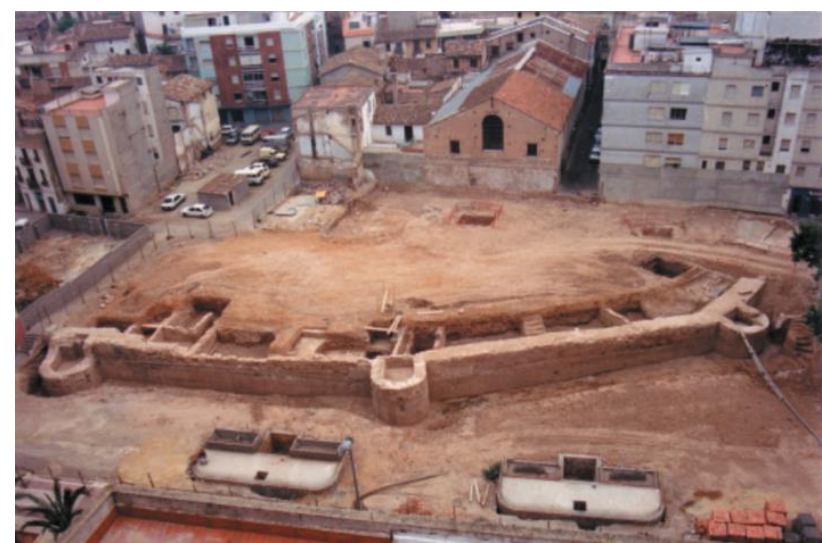

Figure 4. Archaeological excavation of the wall. (PEP - Alzira)

\subsection{Research objectives}

The research project to be developed at the Universitat Politècnica de València "Earthen architecture in the Iberian Peninsula: study of natural, social and anthropic risks and strategies to improve resilience" Risk-Terra (ref. RTI2018095302-B-I00; main researchers: Camilla Mileto and Fernando Vegas) aims to study the response of earthen architecture to natural and social hazards, such as floods, earthquakes, climate change, abandonment, and demographic pressure.

The case study of Alzira and its Moorish wall offers the opportunity to analyse the historical transformations and adaptations in terms of vulnerability, resistance, and resilience of earthen architecture. The case study selected will be taken as a reference for the behaviour of earthen architecture, in its monumental and vernacular dimension, aiming to identify its strengths and weaknesses and obtain examples of best practices.

This investigation will be followed by a study of possible risk prevention and mitigation strategies, to be achieved through the design of structural reinforcements and protective devices.

\subsection{Methodology}

The methodology proposed for this research will be organized into stages of data collection, analysis and verification, using quantitative and quantitative methods to ensure scientifically valid results.

Analysis of direct (interviews, surveys, direct analyses of earthen construction) or indirect sources (analysis of previous studies, best practices, bibliography, risk maps) will be crucial to the comprehensive research. The information compiled must be organic in order to build a complete picture of the knowledge acquired and provide a significant contribution to the research process.

For this purpose, systematic analysis of the sources is useful for establishing the criteria for content analysis and drawing up evaluation forms to catalogue and encode any elements of significance found in the analyses. Similarly, predictions and analyses will help determine the surrounding flood areas, assessing flood hydrographs for the considered return period.

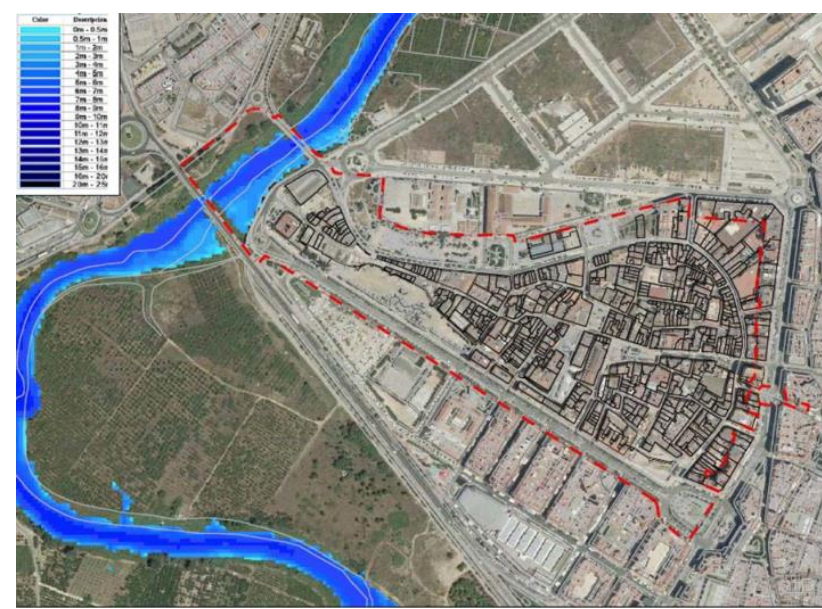

Figure 5. Draught levels.

Return period of 10 years. (SNCZI)

Flood analysis in urban areas is fundamental in defining flood zones and potential risks. The mathematical models used for this introduce simplifications which must be verified through comparison with results obtained empirically.

The size of flood areas can be calculated roughly using a onedimensional permanent motion model; especially in urban areas, although this method is ineffective, as its hypotheses are difficult to apply in areas with complex topographies. Two-dimensional models, mathematically described by De Saint Venant equations (DSV), are used to analyse these areas.

These equations allow detailed analysis of the flow of water within a city, often characterized by preferential directions of movement due to the presence of buildings. The risk will then be assessed taking into account both the water level and the speed achieved by the water flow.

Detailed photogrammetric surveys will be used as references given that correct representation of the urban area within the model is crucial to the definition of the areas of greatest risk.

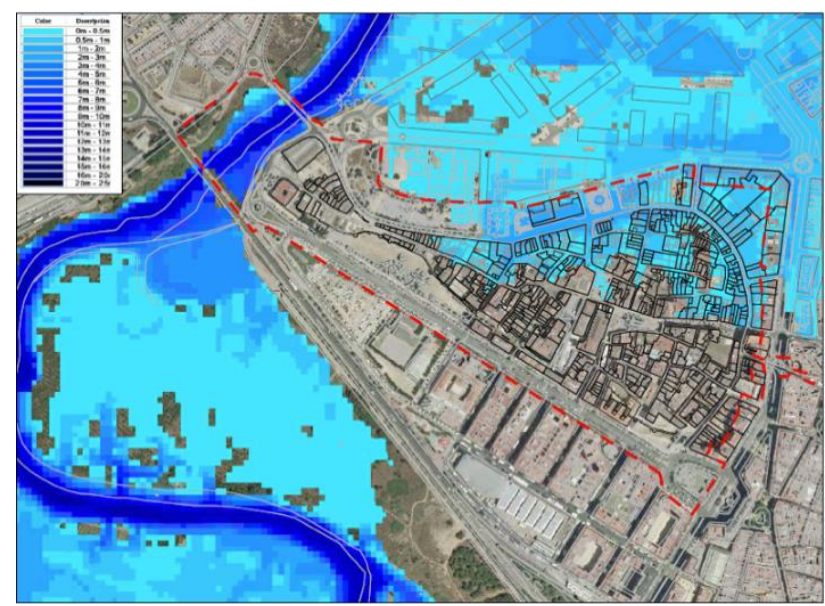

Figure 6. Draught levels.

Return period of 100 years. (SNCZI) 


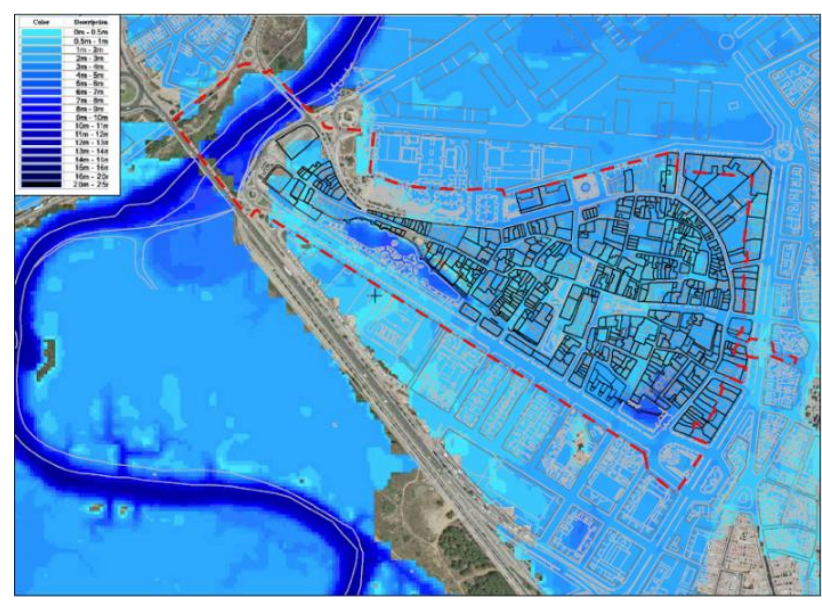

Figure 7. Draught levels. Return period of 500 years. (SNCZI)

The vulnerability factors of earthen architecture under consideration will then be identified, distinguishing susceptibility factors (negative elements that increase risk in relation to danger) and resilience factors (positive factors that mitigate risk). Vulnerability analysis, which is related to damage analysis, will start with the identification of the factors which can cause damage to buildings, and the stresses that can lead to complete collapse of the building, such as hydrostatic and hydrodynamic forces or detritus impact. These factors will be evaluated in relation to the morphology of the building, its construction technique and the state of preservation, highlighting the existing degradation mechanisms and the restoration works already carried out.

Referring to the data collected and catalogued, the following types of vulnerabilities will be studied: environmental, morphological, constructive and sociocultural. Vulnerability will then be calculated taking into account the weighting coefficient, or Building Vulnerability (BV), obtained from the product of standardized factors for its weighting coefficients, and the factor called Human Vulnerability (HV), obtained from the product of BV and the data population. In order to obtain a complete analysis of the case study, the data will be included in the 2D model of the town topography, using GIS technology.

This method will allow the introduction of subcategories characterized by different parameters into the domain. By defining the vulnerability level, intervention strategies will be studied and organized into three levels: 1) to avoid the occurrence of exceptional actions, for example by isolating the structural system from exposure to such actions, thereby reducing the possibility of disaster events; 2) to prevent significant localized structural damage that could trigger unexpected collapse; 3 ) to avoid structural collapse or localized damage through an optimized structural design. An optimal risk prevention strategy should include a combination of the three abovementioned strategies.

Assessing each building element and its traditional construction technique will identify the most appropriate intervention strategies relating to the category of damage.

These strategies will be the ground for the development of intervention proposals for the conservation of earthen architectural heritage, using intervention criteria to ensure maximum respect for historical constructions.

\section{CONCLUSIONS}

The conservation of architectural and cultural heritage is now a fundamental task for the preservation of our history and culture. Now, as in the past, the risk of natural disasters, such as floods, constantly threatens this heritage. Within Spain's vast architectural heritage, earthen architecture is one of the main building traditions and is frequently threatened by floods and torrential rains, amplified by the effects of climate change. Through the study of the case of Alzira, this research will attempt to provide a detailed analysis of the resistance resources of this seemingly fragile and poor architecture, but also to identify conservation strategies. These strategies will be more broadly defined so that they may be applied not only to the case study but also to similar cases.

Finally, it is essential to specify that the interest in the conservation of earthen architecture lies in the fact that it is the cultural heritage, made up of techniques and know-how, which continues to provide ideas for reflection and suggestions for future architecture.

\section{ACKNOWLEDGEMENTS}

This work is part of the research project "Earthen architecture in the Iberian Peninsula: study of natural, social and anthropic risks and strategies to improve resilience" Risk-Terra (ref. RTI2018-095302-B-I00; main researchers: Camilla Mileto and Fernando Vegas), funded by the Spanish Ministry of Science, Innovation and University.

\section{REFERENCES}

AA.VV., 2014: Gestión del riesgo de desastres para el Patrimonio Mundial, UNESCO, Paris.

AAVV, 2008: Riesgos naturales. Guía Metodológica para la elaboración de cartografías en España. COG, Ministerio de Vivienda.

Cirvini, S.A., Gómez Voltan, 2012: Test and device to evaluate capillary absorption in soil specimens of adobe and rammed earth" en Rammed Heart Conservation, Valencia, Spain, 2012. C. Mileto, F. Vegas, V. Cristini (eds.). London: Taylor and Francis Group. p.131-137.

Carmona González, P., Ruiz Pérez, J. M., 2000: Las inundaciones de los ríos Júcar y Turia. Serie Geográfica, Universidad de Alcalá, n. 9, p. 49-69. ISSN 1136-5277

Guillaud, H. 2012: Pisé: Evolution, innovation, resistances and future directions. Rammed Heart Conservation, Valencia, Spain, 2012. C. Mileto, F. Vegas, V. Cristini (eds.). London: Taylor and Francis Group. p.3-8.

Hidalgo Mora, J. 2012: Rammed earth architecture in the middle course of the river Júcar, Spain. Rammed Heart Conservation, Valencia, Spain, 2012. C. Mileto, F. Vegas, V. Cristini (eds.). London: Taylor and Francis Group. p.131-137.

Lairón Pla, A. J., 2017: Alzira y la pérdida de su patrimonio histórico-artístico (1900-2000). Lo que el siglio se llevó. Arquitectura tradicional y patrimonio de la Ribera del Xúquer. Valencia: General de Ediciones de Arquitectura. p.96-109.

Mateo Mansanet, N., 2019: Las Murallas de Alcira (Valencia). Master Thesis. Valencia: Universitat Politècnica de València. 
Matero, F.G., 2012: Earthen Architecture: Clay feet or a feat of clay en Rammed Heart Conservation, Valencia, Spain, 2012. C. Mileto, F. Vegas, V. Cristini (eds.). London: Taylor and Francis Group. p.17-19

Matoses Ortell, I., Hidalgo Mora, J., Planells Pérez, A. (2017). Arquitectura tradicional y patrimonio de la Ribera del Xúquer. Valencia: General de Ediciones de Arquitectura.

Mileto, C., Vegas, F. (Eds.), 2014: La restauración de la tapia en la Península Ibérica, Argumentum/TC. Lisboa/Valencia.

Montagud Piera, B. 1989: Alcira. Estudios artísticos I. Alzira: Comisión Falla Mayor.

PEP - Pla Especial De Protecció De La Vila D'alzira, Refundido 2017.

Phillips H., 2015: The capacity to adapt to climate change at heritage sites. The development of a conceptual framework ESP, 47

SNCZI - Sistema Nacional de Zonas Inundables.

Tabernes Pastor, F., Broseta Palanca, M.T., 2017: El plan especial de protección de la Vila de Alzira. Arquitectura tradicional y patrimonio de la Ribera del Xúquer. Valencia: General de Ediciones de Arquitectura. p.110-117.

Wang, J.J., 2015: Flood risk maps to cultural heritage: Measures and process. Journal of Cultural Heritage, 16, p.210-220.

Warren, J., 2001: Forma, significado y propuesta: objetivos éticos y estéticos en la conservación de la arquitectura de tierra. Loggia, Arquitectura \& Restauración, (12), p.10-19. https://doaj.org/article/c6e0924daf2e484698ed5a8f259e64f6. 